\title{
Toward Lean Construction through Critical Chain Project Management and Root Cause Analysis in a Construction Project
}

\author{
Indrianawati Usman \\ Universitas Airlangga Indonesia
}

\author{
Oktaviano Rendy \\ Universitas Airlangga Indonesia \\ Email = indrianawati-u@feb.unair.ac.id
}

\begin{abstract}
Construction projects have a high risk so that many important factors affect the outcome of a project called 5M, which are: man, money, material, method, and machine. Furthermore, there are other factors that must be considered, which is the uncertainty of environmental conditions. Recently, there is a method for scheduling a project that can be used to deal with the uncertainty, namely Critical Chain Project Management (CCPM). Meanwhile, there is a methodology and a well-known control technique called Earned Value Concept, which is a method to analyze the time comparison of planning with the reality in the field. The results of this comparison are used to schedule control system criteria. Through Critical Chain Project Management and Root Cause Analysis methods, the use of the lean construction concept can be used optimally.
\end{abstract}

Key Word : Critical Chain Project Management, Root Cause Analysis, Earned Value Management, Project Management, Project Construction

\section{Introduction}

The problems that often arise in the construction project are a discrepancy between the initial plan and the realization of the project implementation. Such discrepancies will interfere the work in progress that may have implications for late project completion. The presence of waste or non-value added activity leads to a mismatch of schedule designs with actual field processes that can result in significant cost wastage. Generally, there are some wellknown traditional scheduling methods, namely; Gantt chart, Program Evaluation and Review Technique (PERT) and Critical Path Method (CPM). However, there is a new project scheduling method that is used recently to deal with the uncertainty of critical chain project management (CCPM). Goldratt first introduced critical Chain Project Management in 1997. Critical Chain Project Management is an effort to implement Theory of Constraints (Leach, 1997). One of the advantages of using Critical Chain Project Management is the calculation of buffer distances containing duration of work (Alexandra and Machado, 2007). When using Critical Chain Project Management correctly, it will improve the performance of project work (Huang et al, 2013). By using time buffer, the company can avoid the existence of student's syndrome, which is a tendency to perform activities when approaching the deadline. Another advantage of CCPM is buffer management or time buffer monitoring to signal the executor to take immediate action so that the project can be completed on time and not wasting the expenses.

Construction projects have a very high risk. This should be managed and controlled properly to ensure the smoothness of the development process, because all these factors can lead to waste of expenses. One of many tools to manage risk and minimize costs is by using Root Cause Analysis (RCA). According to Grant Kululanga, et al (2010) contractors should be able to assess the emerged risks, Marks Dogget (2010), said that there is always a cause in every problem. Shri Ashok Sarkar et al (2012) states that $\mathrm{RCA}$ is one of the most useful themes. In the RCA there are several tools that can be used, they are; cause and effect diagram and interrelationship diagram. The well-known and often-used method of controlling is the concept of Earned Value Concept that analyzes the usage of time period with the planning. Based on the acknowledgment of project managers who become the object of research, the majority of failures in the construction of a project are because of overtime and over budget, which is about $40 \%$ to $60 \%$.

The purpose of this research is to optimize lean concepts through the implementation of critical Chain Project Management and Root Cause Analysis on a project.

\section{Theoretical Background}

Project management has been developed since 1950. Since the development of PERT and CPM methods, project management has begun to be used simultaneously in both manufacturing and construction. Project management has three phases, namely the planning phase, the scheduling phase and the control phase. Atkinson (1999) states that project management is the application of a collection of tools and techniques to guide the use of diverse and limited resources against unique, complex, time-limited, cost, and quality constraints. Kerzner (2006), stated that project management is a work in which consists of planning, organizing, organizing, directing, and controlling corporate resources for a relatively short period of time to achieve the intended purpose.

Project management is carried out through application and integration of project management process stages: initiating, planning, executing, monitoring and controlling and finally closing the entire project process. The situational approach (contingency) states that the task of management 
is to identify techniques and methods that must be used to handle a particular type of activity at a given time and condition. Construction project planning includes the process of determining the scope of the project, the formulation of the structure and hierarchy of the project, the selection of technology and construction methods, the formulation of activities, the estimated resources required and the duration for each activity, and the identification of linkages between activities. According to Michael B., Daniel, and James (1992) project planning has the goal of directing the project objectives, identifying actions, guiding ongoing project activities, preparing project changes and preparing project changes. Project scheduling is the elaboration of project planning into a sequence of steps of the work implementation as well as the allocation of activity time to complete the project to achieve optimal results with attention to the limitations (Callahan and James, 1992).

Project time management includes the all the necessary processes to ensure that the project is completed within a certain period of time which covers five processes, namely; activity definition, activity sequencing, activity duration estimating, schedule development, and schedule control. Uncertainty can affect a traditional scheduling process that is already being predicted precisely. There are four dimensions of uncertainty in scheduling, they are; the technical planning stage characterized by different degrees of experience, procurement stages characterized by the number of activities at different locations. The risk factors at this stage are related to the selection of contractors, vendors and time delivery. In the construction phase there is a risk of construction projects, which is the selection of contract format that is less appropriate according to the characteristics of the project.

\section{Critical Chain Project Management (CCPM)}

Critical Chain Project Management is a project scheduling and control method that is developed from a methodology called Theory of Constraints (Goldratt, 1990). Theory of Constraints approach focuses on the timeline completion of work on the project as a whole. According to Theory of Constraints each project will be influenced by one or several resource constraints where the limiting capacity within the activity affects the overall duration of the project.

There are five steps to the theory of constrain approach, they are:

1. Identify system boundaries. 2. Decide how to take advantage of system restrictions. 3 . Lower the others to the decision. 4. Increase the system boundary and 5. Return to the initial step and not letting the delay cause the system restrictions. CCPM is a method of planning and managing projects that emphasize the needed resources to carry out project tasks. This method differs from the traditional methods such as critical paths and PERT, which emphasize tasks and scheduling rigidly. This method attempts to maintain resource adequacy and scheduling accuracy by using the buffer level, which are used as a reference to determine the length of delay, so that the project manager can easily estimate the length of the project. CCPM uses three theories to apply in improving the performance of a project. These three theories are Theory of Constraint, Common Cause Variation and Statistical laws governing common cause variation.
There are three steps of CCPM. First, planning, which contains Critical chain, estimation and safety. In CCPM there are three buffer types: buffer project, feed buffer and resource buffer. Both execution consist of resources priorities, completion. Finally, review, which consist of buffer management and remaining duration. Buffer is some sort of a protection in a management to cover uncertain tihings. The Tocico Dictionary defines buffer management as a feedback mechanism which is used during the operational, distribution and project management phase that provides the means to prioritize a job, to know when to accelerate a work period, to identify where insufficient shielding capacity, and to resize if needed.

According to The Tocico Dictionary there three zones related to the usage of buffer, namely:

a) Green Zone (expected variation)

In this zone, there is time that has been collected in a critical chain buffer that serves to protect the project completion date. If all activities are running according to a critical chain schedule, some or all buffers will be used and this project will be completed on time or before the scheduled date. In this green zone as a result of the working project, it can be expected that one-third of the buffer will be used because of the emerging uncertainty.

b) Yellow Zone (normal variation)

The utilization of two thirds of the critical chain buffer is usually caused by the uncertainty that is part of the prediction of the duration of the work. Small variations in project operations are not a reason to take action, but if two-thirds of buffers start to be used to cover overloaded tasks, then a plan should be designed to improve the time lost.

c) Red Zone (abnormal variation).

The specific causes of abnormal variations are sometimes the result of unexpected events from the external and internal of the project during the working progress.

\section{Earned Value Management (EVM)}

Earned Value Management (EVM) is a project performance measurement technique that integrates scope, time and cost data. Based on the cost performance baseline, the project manager and his team can determine how well the project meets the scope, time and cost objectives by taking into the account of the actual information and comparing it with the baseline (PMBOOK, 2004). Earned value method $(E V M)$ is a project control technique that uses quantitative calculations to measure work performance (Mofid and Naderpour, 2011). Earned Value Management includes the calculation of 3 values for each activity or summary activity of the WBS project, Planned Value (PV), Actual Cost (AC) and Earned Value (EV). 


\section{Lean Construction}

Lean construction is an extension of the main objective of the lean production system, which maximizes value and minimizes waste for a specific technique and implement it to the process of delivering new project values (Lean Construction Institute, 2012). Lean construction is a practical application of the lean manufacture principle or lean way of thinking into the construction area (Lukowski, 2010). Lean talks about the balance between people, materials, and resources. This allows companies to reduce costs, eliminate waste and deliver or complete a job in a timely and appropriate quality (Lim, 2008). Lean construction and lean production are understood as a collection of a technique, analysis, social-engineering paradigm, or even cultural commodities (Green and May, 2005). Bertelsen, 2004 stated that Lean construction is a large-scale adaptation derived from Japanese manufacturing principles and this concept is implemented into the construction process. While Howell, 1999 states that Lean construction is an ongoing practice as a goal to enhance the organization's ability to deliver what consumers need in a better way by using fewer resources.

Waste adalah segala sesuatu yang tidak memiliki nilai tambah. Waste tidak hanya berupa material yang terbuang, tetapi juga sumber daya lain secara luas, termasuk waktu, energi, area kerja. Dilihat dari sudut pandang nilai tambah, maka segala aktivitas yang kita lakukan dapat dibagi menjadi 3 kelompok besar:

1. Aktivitas Bernilai Tambah atau dikenal dengan ValueAdded Activities (VA)

2. Aktivitas Tidak Bernilai Tambah atau dikenal dengan Non-Value-Added Activities (NVA)

3. Aktivitas Tidak Bernilai Tambah tetapi Diperlukan atau dikenal dengan Value Enabler Activities atau Business Non-Value-Added Activities (VE atua BNVA)

Waste is anything that has no added value. Waste is not only a waste of material, but also other resources widely, including time, energy, and work area. Observed from the added value point of view, then all the activities we do can be divided into 3 major groups:

1. Added Value Activities or known as Value-Added Activities (VA)

2. Non-Value Added Activities Known as Non-ValueAdded Activities (NVA)

3. No Value Added Activity but Needed or Known by Value Enabler Activities or Business Non-Value-Added Activities (VE or BNVA)

There are 7 types of waste, which are known in Lean, namely:

1. Waste of transport - This waste consists of unnecessary transfers or transportation such as temporary placement, reassembling, and moving goods

2. Waste of excess inventory - This waste includes inventory, stock or excessive inventory

3. Waste of movement - time and energy used for non value-added movements, including for example seeking, inefficient and non-ergonomic movements
4. Waste of waiting - This waste includes activities such as auto attendance, waiting for goods to arrive, waiting for approval

5. Waste of excess production - produce the product exceeds demand, or earlier than schedule

6. Waste of over process - any addition of processes that are not required for products that will only increase production costs.

7. Waste of defect or defective product - including rework, rework no value added

WBS is a method of organizing projects into a hierarchical reporting structure. WBS is used for solving each work process into more detail. In principle Work Breakdown Structure (WBS) is the breakdown or division of work into smaller sections (sub-activities), WBS assists in monitoring and forecasting costs, schedules, and productivity information that convince project management members. By utilizing a list of jobs on the WBS, an organization will be able to estimate the length of time it takes to complete each job (PMBOOK, 2004).

\section{Root Cause Analysis}

Root Cause Analysis (RCA) is a process design structure that is used to assist an organization in knowing a problem that was or is happening at a time, understand the cause of the problem and look for the type or kind of problem solving. Once a solution has been confirmed its effectiveness then this solution should be able to be channeled to all elements within the organization and ideally applied where the same cause creates the risk.

\section{Research Method}

This research uses case study explanatory approach. The analysis will refer to a lean thinking concept adapted to lean project management based on Critical Chain Project Management and Root Cause Analysis methods. Performance measurement uses the $\mathrm{S}$ and Earned Value Management Curves that have been commonly used in the construction world. Critical Chain Project Management is strongly influenced by the concept of Theory of Constraint (TOC). There are five stages developed by (Goldratt and Cox, The Goal, 1986) applied into project management (Goldratt, 1998). The research stages consist of the following stages:

1. Identify, this is the stage of finding constraints that limit performance. In the case of production management, is finding a weak relationship in the production chain, resource or workstation that will or has caused a bottleneck. However, in project management is to identify critical chain. Critical chain is the longest chain of previous work and source of constraints.

2. Exploit, this stage is done to improve system performance with available resources. In this project, critical chain is functioned to ensure the work takes place efficiently and without delay. However, in the case of multi-project is defined to manage the distribution of resources to critical areas. This is done 
by phase, first by prioritizing the project and secondly avoiding any multitasking work so that the resource bottleneck has been completed before proceeding to other lower project priorities.

3. Subordinate, using slack or more capacity in nonbottleneck resources in order to improve the performance of the bottleneck resources. In its critical chain the emphasis is to reduce the uncertainty in performance at the completion time limit. Implementation within this project means uncritical activity should not interrupt or delay critical activity.

4. Elevate, if the system performance is not satisfactory after taking the above steps, then the whole capacity of the whole project is focused on the bottleneck constraint. This leads into investing in additional resources. In general, the focus will be on increasing the capacity of resources that have the greatest impact in the critical chain or total output of the system.

5. Goals, in the world critical chain, the initial project schedule is designed to minimize the duration of the project under resource constraints, so that objectives will provide direction in designing the critical paths for the three major constraints in the project which are; cost, time, and resources.

The object of this research is the development process of Plant 5 Dawuan Astra International by PT. Bhineka Cipta Bahana Pura. The geographical conditions on the project site is an industrial area located in the town of Karawang, Dawuan.

Data collection in this study was conducted with Focus Group Discussion, the primary data used in the solution chart on the Root Cause Analysis concept. Respondents used in the Focus Group Discussion are from external and internal parties who are directly involved in project development. This research uses triangulation technique to check the validity of data. Triangulation is a technique of examining the validity of data that utilizes something else in comparing the results of the interview or discussion of the object of research (Moloeng, 2004). Triangulation type used in this research is data triangulation, Root Cause Analysis result adjusted to result of Focus Group Discussion by external party of construction company with internal company involved in the working project.

\section{Analysis and Result.}

1. Here are the steps in the scheduling development in the critical chain method:

2. Create a project initialization schedule by removing the safety time of any duration of activity.

3. Scheduling from the end of the project as well as eliminating resource conflicts.

4. Identify the longest path of resources and activity dependencies.

5. Calculates and inserts project buffer projects based on the size of the project buffer that is typically 50 percent of the total length of the critical chain duration.

6. Calculating and inserting feeding buffers into all connected chains within a critical chain, intended to eliminate resource conflicts arising within the project.
7. Add a resource buffer interaction to guarantee resources that have no predecessor job in starting the job and against all the resources that have been specified in the critical chain.

The work in the AHM Project Package 3 consists of two summary task groups that have subordinate tasks as described with Work Breakdown Structure (WBS) which provides a common framework for planning and controlling work to be carried out. The duration of this project is 307.36 calendar days (from 9 July 2014 to 31 May 2015). There are 68 activities to complete the scope of the AHM Packaging 3 machining building. In the scheduling of the AHM Project Development Package 3, The Machining Section of the dependence relation or the interrelationship between the work can be seen in the bar chart of the Microsoft Project Scheduling Program, which is principled on the Critical Path Method calculation, and with the bar chart display, which can show the relation between each job and critical path.

The progress rate for each activity is calculated based on the percentage comparison of the cost of each activity that is calculated based on the material value and the wage of labor with the total cost of the project proposed by the owner, which is IDR 32.778.353.877,00. The working progress rate measurement will be illustrated through $\mathrm{S}$ Curve, by comparing S-Curve work planning and actual job realization. If the two curves are combined, it will show the progress of the work clearly, whether the project experiencing delays or even inefficiency which is seen from how big the slope and comparison of the curve.

Development of the schedule is done by Critical Chain Project Management method that describes the relation of job dependency, eliminates at the place of resource constraint. In the AHM construction project Package 3 machining party is in the plastering and sanitation work and the first step is to eliminate the safety time by using the concept of probability of completion time of each work. The concept of probability is calculated based on the average implementation of a project activity, cutting duration cannot be done roughly by cutting $50 \%$, as it will affect the calculation of working hours for human resources as well as the capability of material suppliers.

After the cutting process, then the next task is to determine the placement of feeding buffer and project buffer that will be able to remove the constraint, in this project after some evaluation it is decided that feeding buffer is placed on the architectural work so that it is able to eliminate constraint resources and improve the ability of the project buffer to absorb Critical path. The size of the buffer project is calculated by using the cut \& paste method $(\mathrm{C} \&$ $\mathrm{PM}$ ), which is taken by the management deadline, specified by the owner, stated in the contract that is scheduled by $20 \%$ of the final project, but to increase the buffer effectiveness rate is taken by $17 \%$. With a total duration of work is 307.36 days, then: 
Project buffer $=307,36$ days $\times 17 \%$

$$
=53 \text { days }
$$

feeding buffer is stated through following calculations :

$$
\begin{aligned}
& \text { Feeding buffer } \\
& \qquad \begin{aligned}
\text { machining architecture } \\
=\sum \text { duration (steel ladder works } \\
+ \text { plastering works } \\
\quad+\text { sanitation works) } \times 17 \% \\
=201 \text { days } \times 17 \%=34,17 \text { days }
\end{aligned}
\end{aligned}
$$

After forming a network diagram with the Critical Chain Project Management method then the next step is to evaluate the results of the project report (weekly report) that can be used for project performance measurement (updating).

\section{Result}

1. Based on the final outcome of the development schedule using the critical chain method of the schedule resulting faster project implementation time compared to the execution time used for the initial master schedule, this is because in the Critical Chain Project Management method analysis is done by cutting the duration of the work to eliminate Safety time. Using Critical Chain Project Management, critical paths generated by the first master schedule using CPM (Critical Path Method) are no longer needed, due to the absorption of critical paths by project buffers that serve to reduce critical paths and reduce waste.

2. By using RCA (Root Cause Analysis), construction companies can improve effectiveness in handling problems and job risks, this actually has a positive impact on the planning schedule of Critical Chain project Management method.

3. Based on the results of S-Curve, we get the value of the weekly work realization which shown a greater value compared with the value of the weight of the planned work, which is able to maximize the use of resources.

4. Through the Critical Chain Project Management and Root Cause Analysis methods, the company can maximize the use of the lean construction concept that has been able to represent the nature of lean. With the nature of lean being represented it can be concluded that the company is able to reduce the seven waste on the construction project.

5. To ensure the accuracy and efficiency of materials and labor, it is expected that the lean principles combined with Critical Chain Project Management and Root Cause Analysis methods can be applied by all construction projects and High Risk Building.

6. Further research is expected to use the work as a whole, so that the research becomes more interesting and can be done in more depth analysis.

\section{References}

[1] Alexandra, T. \& Machado, C. V. (2007). Critical Chain Project Management : A New Approach For Time Buffer Sizing. Industrial Engineering Research Conference, 475-480.

[2] Naderpour dan M. Mofid. (2011). Improving Construction Management of an Educational Center by Applying Earned Value Technique. Procedia Engineering, 1945-1952.

[3] Cox III, J.F., \& Schleier, J.G. (2010). Theory of Constraint Handbook. McGraw Hill

[4] D. K. H. Chua, M.ASCE, and L. J. Shen, Key Constraints Analysis with Integrated Production Scheduler; The Journal of Construction Engineering and Management, Vol. 131, No. 7 1, 2005

[5] Dogget, A. M. (2005). Root Cause Analysis : A Framework for Tool Selection. The Quality Management Journal.

[6] Godratt, E. M. (1997). Critical Chain. Massachusetts; North River Press.

[7] Goldratt, E. M. (1998). Theory of Constraint; North River Press

[8] Goldratt, E. M \& Cox, J. (1986). The Goal. North River Press.

[9] Herroelen, W., and R. Leus, "On the Merits and Pitfalls of Critical Chain Scheduling," Journal of Operations Management, 19 (2001), pp. 559-577.

[10] Huang, C., Li, R., Chung, Y., Hsu, Y., Tsai, C. (2013). A Study of Using Critical Chain Project Management Method for Multi-Project Management Improvement. International Journal of Academic Research in Economics and Management Sciences, 2226-3624.

[11] Kululanga, G \& Kuotcha, W. (2010). Measuring Project Risk Management Process for Construction Contractors with Statement Indicators Linke to Numerical Scores. Engineering, Construction, and Architectural Management, 336-351.

[12] Leach, L. P. (1997). Critical Chain Project Management Improves Project Performance, Advanced Project Institute, Idaho Falls, USA.

[13] Mullohand, B. \& Christian J., Risk Assessment in Construction Schedule, ASCE Journal of Construction Engineering and Management Vol. 125 No. 1, 1999, Page 8-15

[14] PMBOOK. (2004). A Guide to the Project Management Body of Knowledge, Third Edition, Project Management Institute.

[15] Sarkar, S. A. \& Mukhopadhyay, A. R. (2013). Root Cause Analysis, Lean Six Sigma and Test of Hypothesis. The Technology Quality Management Journal, 170-186.

[16] Steyn, H. 2002. Project Management Application Of Tthe Theory Of Constraintts Beyond Critical chain Schedulling. Internasional Journal of Project Management, 75-80.

[17] Rand, G.K., "Critical Chain: The Theory of Constraints Applied to Project Management," International Journal of Project Management, 18:3 (2000), pp. 173-177. 
[18] Raz, T., R. Barnes, et al., "A Critical Look at Critical Chain Project Management," Project Management Journal, 34:4 (2003), pp. 24-32.

[19] Tague, N. R. (2005). The quality toolbox. (2th ed.). Milwaukee, Wisconsin: ASQ Quality Press. Available from

http://asq.org/qualitypress/displayitem/index.html?ite $\underline{\mathrm{m}=\mathrm{H} 1224}$ 